\title{
Correction to: The Harmful Effect of the Hydro-Electric Dams Upstream of the Mekong River: Effect on the Ecosystems and Livelihoods of People in Mekong Delta, Vietnam
}

\author{
Ba Le Huy ${ }^{1} \cdot$ Hung Le $^{2} \cdot$ Hoan Nguyen Xuan ${ }^{1}$
}

Accepted: 2 November 2021 / Published online: 25 November 2021

(c) Springer Nature Singapore Pte Ltd. 2021

\section{Correction to: Water Conservation Science and Engineering https://doi.org/10.1007/s41101-021-00112-1}

The original version of this article unfortunately contained incorrect article title.

The corrected article title is presented above.

The original article has been corrected.

Publisher's Note Springer Nature remains neutral with regard to jurisdictional claims in published maps and institutional affiliations.

The original article can be found online at https://doi.org/10.1007/ s41101-021-00112-1.

Ba Le Huy

lhuyba@gmail.com

1 Ho ChiMinh City University of Food Industry (HUFI), Ho ChiMinh City, Vietnam

2 Ho Chi Minh City Nature-Environmental Society, Ho Chi Minh City, Vietnam of Geographical Sciences, Northeast Normal University, Changchun 130024, China 